March 2021

WORLD PEACE

:oundation

\title{
Business as Usual: \\ How major weapons exporters arm the world's conflicts
}

Defense Industries, Foreign Policy and Armed Conflict Report 1

By Sam Perlo-Freeman 


\section{Business as Usual: How major weapons exporters arm the world's conflicts}

Defense Industries, Foreign Policy and Armed Conflict program 


\section{ABOUT}

The World Peace Foundation, an operating foundation affiliated solely with the Fletcher School at Tufts University, aims to provide intellectual leadership on issues of peace, justice and security. We believe that innovative research and teaching are critical to the challenges of making peace around the world, and should go hand-inhand with advocacy and practical engagement with the toughest issues. To respond to organized violence today, we not only need new instruments and tools-we need a new vision of peace. Our challenge is to reinvent peace.

Dr. Samuel Perlo-Freeman is a Research Coordinator at Campaign Against Arms Trade in the UK, focusing on UK military spending and arms procurement. He is also a Fellow at the World Peace Foundation. While working at WPF, he led the project to create the Compendium of Arms Trade Corruption. Previously, he was Senior Researcher at the Stockholm International Peace Research Institute (SIPRI) from 2007 to 2016, working on issues of military expenditure, arms industry and arms trade. As head of the SIPRI Military Expenditure project, he completed a project in 2016 to extend SIPRI's unique military expenditure database backwards in time from 1988 to the 1950s. He holds PhDs in Mathematics and Economics, and is the author of numerous publications on military expenditure, the arms industry and trade, defence and peace economics, development economics, and mathematics.

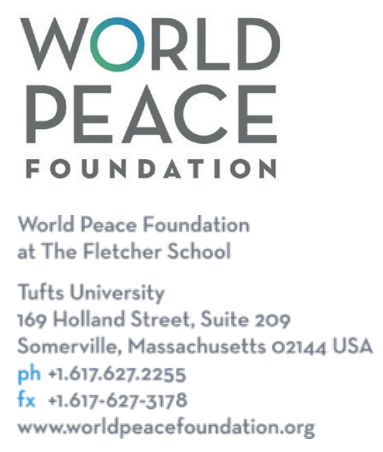

THE FLETCHER

SCHOOL

TUFTS UNIVERSITY 


\section{TABLE OF CONTENTS}

\section{EXECUTIVE SUMMARY}

1. Introduction

2. Controlling the international arms trade

3. Conflict and Arms Exports in the $21^{\text {st }}$ Century

4. Statistical Analysis of Conflict and Arms Sales Data

5. Conclusions 


\section{EXECUTIVE SUMMARY}

The harmful impact of arms transfers on conflict has been well-documented by campaigners, humanitarian NGOs, and the United Nations. ${ }^{1}$ Further, researchers have found evidence that arms transfers to a state increase the likelihood of conflict breaking out; and, once begun, render conflicts longer and more deadly.

Recognizing these detrimental impacts, in recent decades, policymakers committed to a range of measures designed to control arms exports. These controls were especially focused on limiting sales when conflicts involve patterns of human rights abuses and violations of international humanitarian law. In subsequent years, there have been heated debates about whether sales should proceed in a number of particular instances, but there is no comprehensive assessment of the overall impact of policies designed to limit arms sales to countries involved in conflicts.

This research provides the first global analysis of how conflict in, or involving, a recipient state, impacts exporters' willingness supply arms. It analyses the top eleven global arms suppliers over the ten-year period 2009-2018. ${ }^{2}$ Listed in order by the volume of major conventional weapons transfers, these global sales leaders are: the United States, Russia, Germany, France, China, the United Kingdom, Spain, Israel, Italy, the Netherlands, and Ukraine. These countries assert widely varying formal policies regarding arms exports, but the empirical record is, for the most part, remarkably similar.

\section{Key Findings}

1

There is very little evidence that war or armed conflict leads to restraint in arms transfers by major exporters, regardless of whether their stated policies suggest they should. All major arms exporters supplied substantial volumes of arms to at least some of the wars of the current century.

2 There are no clear cases where the outbreak of war was accompanied by a halt in arms sales by a major exporter. In cases where exporters did not supply arms to a war, the recipient(s) tended to be smaller, poorer countries where demand for arms is lower ('low stakes' cases), even in wartime. Clearly political factors also prevail in some cases, for example where the supplier and recipient had a hostile relationship, or where the recipient had been regarded by (western) suppliers as a 'pariah' long before the outbreak of war (e.g. Iran and Syria).

3 There are some differences among the eleven top arms exporters covered in this report: Russia supplied arms to the greatest number of wars; and Ukraine, the smallest of the exporters, was a significant conflict supplier in relation to its overall level of exports. Even so, the difference between these countries and the US and western European suppliers, was relatively minor.

4 For some exporters (Russia, France, Israel, Spain, and the Netherlands), conflict appears to be associated with a higher probability of transfers. For the other seven, it made no significant difference either way.

5 Rather than conflict, demand factors - levels of GDP and military spending, and the overall level

5 of arms acquisitions by a particular country - were key determinants of whether a given exporter would supply arms to that country.

6 US and European exporters sometimes displayed a pattern of selective, 'Iow stakes' restraint, including cases where they imposed arms embargoes in direct response to conflict or repression. These tended to be cases where opportunities for sales were in any case limited. recipient's conflict status at any particular moment in time. 
In summary, there is little or no evidence that participation in war or armed conflict made it less likely for a country to receive arms from any of the major exporters. The lack of arms supplies to a conflict party appears, in the great majority of cases, to be more likely the result of limited demand, or political factors that are much broader than, and often predate, the conflict. Thus, exporters have generally exercised restraint only in 'low stakes' cases where there was limited potential for sales in any case.

This report is part of a series of reports in the World Peace Foundation research program, "Defense Industries, Foreign Policy and Armed Conflict," which is funded the Carnegie Corporation of New York. It does not attempt to answer questions about why arms were transferred to countries where conflicts were taking place despite some exporters' clearly-stated policies against exporting arms that are likely to exacerbate conflict or to lead to violations of IHL. Detailed analysis of this question will be left to the next stage of the project, involving case studies of the US, UK, and France. These case studies will analyze factors that may influence arms export decision-making processes, including relationships between governments and defense industrial interests, public opinion, and foreign policy considerations. 


\section{Introduction}

The harmful impact of arms transfers on conflict has been well-documented, by campaigners, humanitarian NGOs, and the United Nations. ${ }^{3}$ Several academic studies have also found evidence that arms transfers to a state tend to increase the likelihood of conflict breaking out, or increase the likely duration or intensity of conflict. This report, the first in a series planned as part of a research project, Defense Industries and Armed Conflict, approaches the relationship between arms transfers and conflict from the opposite perspective: does conflict in, or involving, a recipient state, affect the willingness of exporters to supply arms?

\section{Yet, the global arms trade has proven remarkably resistant to effective controls - with direct enabling consequences on conflict situations.}

Recognizing these detrimental impacts, over the last decade, policymakers created a range of international treaties, national legislation and policy, and the EU Common Position, designed to control arms exports. These controls were especially focused on limiting sales when conflicts involve patterns of human rights abuses and violations of international humanitarian law.

Yet, the global arms trade has proven remarkably resistant to effective controls - with direct enabling consequences on conflict situations. This is largely because the trade is driven by powerful security relationships that are a mixture of: (a) foreign policy, (b) national security/defense industrial concerns, and (c) major corporate interests.
As a result, there are numerous examples of major arms producers continuing to provide lethal arms to countries engaged in armed conflicts. These conflicts have had devastating effects on civilians and involved severe violations of International Humanitarian Law (IHL). Most prominent, at present, are the wars in Syria and Yemen, although they are far from the only cases. In the former, the principal arms supplier to the Syrian regime is Russia, a country that makes few if any pretensions of applying humanitarian, human rights, or conflict-related criteria to its arms export decisions. However, in Yemen, where the military intervention by Saudi Arabia, the United Arab Emirates (UAE), and their coalition partners has created the world's worst humanitarian crisis, the main arms suppliers are the US, UK, and France. Each of these countries has arms export rules aiming to prevent the supply of arms that might worsen conflict or be used for human rights or IHL violations.

Focusing on the top eleven exporters of major conventional arms, the report assesses arms supplies by these states to parties to the major armed conflicts of the $21^{\text {st }}$ century. In particular, it assesses three major questions. First, whether there is evidence of patterns in terms of which conflicts they have and have not supplied. Second, whether and when exporters engage in active restraint in relation to arms supplies to certain conflicts. And third, whether and when, on the contrary, exporters have used conflict as an opportunity to increase arms sales. ${ }^{4}$

The research adopts two methodologies. First, a descriptive analysis directly juxtaposes arms sales and conflict data, revealing numerous examples of major arms producers continuing to provide lethal arms supplies to recipients engaged in major armed conflict. This analysis is based on conflicts that reached the status of "War" in at least one year since 2000, according to the Uppsala Conflict Database (UCDP). 
Second, a statistical regression analysis for each exporter, using data from 1990-2018, explores statistical evidence as to whether a recipient state's involvement in armed conflict has any impact (positive or negative) on arms transfers from the exporter in question. This analysis allows us to control for a range of other relevant demand and supply factors, for example the level of military spending or GDP of the recipient, and thus may tease out relationships between conflict and arms transfers over the data as a whole.

The picture that emerges from these two methods of analysis is that there is little or no empirical evidence that participation in war or armed conflict made it less likely for a country to receive arms from any of the major exporters. The lack of arms supplies to a conflict party appears, in the great majority of cases, to be more likely the result of limited demand, or political factors that are much broader than, and often predate, the conflict. Thus, exporters have generally exercised restraint only in 'low stakes' cases where there was limited potential for sales in any case.

Section 2 of this report discusses efforts in recent decades to strengthen arms export controls, and briefly sets out the stated arms export policy framework in the eleven top suppliers.
Section 3 sets out the descriptive analysis of which exporters have supplied arms to which conflicts, and what evidence their patterns of arms supply in war and peace time may provide of restraint, or the reverse. Section 4 summarizes the methodology and results of the regression analysis. Section 5 draws out the key conclusions from the above analysis, and discusses the implications for the ongoing research.

\section{Controlling the international arms trade}

Most arms-producing countries permit and promote arms exports for a number of reasons. ${ }^{5}$ First, exports may spread the high capital and R\&D costs of producing major systems, and maintain the viability of the industry in the gaps between limited domestic orders. Second, arms exports are often used as a tool of foreign policy, to assert global or regional influence, secure foreign basing rights, strengthen the capabilities of allies and partners, balance against rivals, or seek to influence the policy choices of recipients. Third, arms exports carry weight in public debates around employment. While arms production is generally a very small share of the overall

The selection of the top arms exporting states included in this study was based on Stockholm International Peace Research Institute (SIPRI) data on the volume of major conventional weapons transfers over the ten-year period 2009-2018. We decided to focus on the top eleven arms exporters during this period. While a top ten might be more usual, we decided to include Ukraine as it offers an additional case of an emerging, non-Western supplier. The top eleven are, in order:
1) The United States
5) China
9) Italy
2) Russia
6) The United Kingdom
10) The Netherlands.
3) Germany
7) Spain
11) Ukraine
4) France
8) Israel 
economy, major deals may support a large number of jobs concentrated in particular areas, creating strong lobbies in their favor.

At the same time, arms producing states have always sought to exercise some control over exports for various reasons; for example, avoiding selling arms to a military rival or to a recipient seen as acting contrary to the exporter's foreign policy interests; or maintaining an advantage in cutting-edge military technologies. However, it was largely after the end of the Cold War that international efforts to encourage greater restraint in conventional arms transfers began in earnest, and in particular to develop controls reflecting humanitarian concerns and conflict prevention.

The 1991 Gulf War in particular highlighted the dangers of uncontrolled arms transfers, and the potential for 'blowback' for exporting states. Measures included the UN Register of Conventional Arms, a voluntary transparency measure established in 1991, ${ }^{6}$ and the 1995 Wassenaar Arrangement, signed by most major arms exporters including the US and Russia. ${ }^{7}$ Both of these cited a goal of avoiding 'destabilizing accumulations' of arms.

The 1990s also saw efforts to control the widespread proliferation of small arms and light weapons (SALW) in the global South, where their use in numerous devastating conflicts led to appalling levels of civilian death, injury and displacement. The UN Programme of Action on SALW, adopted in 2001, promoted tighter restrictions on the legal trade, and bolstered efforts to tackle illicit trade. ${ }^{8}$ The international treaties banning anti-personnel landmines (1997) and cluster munitions (2008) are other important elements of the development of humanitarian arms controls.

However, it was not until 2013 that a binding international treaty, the Arms Trade Treaty (ATT), was signed to cover principles of restraint for the conventional arms trade in general. The ATT was the culmination of years of campaigning by affected states and international civil society. It requires State Parties to establish a system of controls on arms exports, imports, and transit, and sets out criteria by which they should evaluate their potential exports, including ones relating to conflict, human rights, and IHL.

The extent to which conflict, IHL, and human rights concerns are reflected in export control laws and policies of the main producing countries nonetheless vary considerably.

\section{A. The European Union (EU) - Germany, France, United Kingdom, ${ }^{9}$ Spain, Italy, Netherlands}

Following a major scandal over arms sales to Iraq in the 1980s, the New Labour government under Prime Minister Tony Blair that came to power in 1997 promised tighter controls on arms exports, as part of an "ethical dimension" to foreign policy. While the Blair government's record fell far short of campaigners' hopes, the UK also became a leading voice in efforts towards stronger controls at the EU level, in an effort to "level the playing field" with other European exporters. This led in 1998 to the EU Code of Conduct on arms exports, a politically binding agreement which enshrined conflict, human rights, and international humanitarian law, among other criteria, as key factors in arms export licensing decisions. It was upgraded in 2008 to a legally binding EU Common Position, and also served as a partial model for the ATT, of which all EU members are State Parties.

The Common Position forbids export licenses for arms transfers that would "provoke or prolong armed conflicts or aggravate existing tensions or conflicts" (Criterion 3), or if there is a "clear risk" that they might be used to violate IHL (Criterion $2 \mathrm{c}$ ), or that they would be used aggressively 
against another country (Criterion 4).

\section{B. The United States}

The United States signed the ATT in 2013, but did not ratify it. ${ }^{10}$ However, the principle that arms transfers should not inflame conflict is enshrined in US legislation. Section 2778 of the Arms Export Control Act of 1976 (para. (a)(2) states:

"Decisions on issuing export licenses under this section shall take into account whether the export of an article would contribute to an arms race, aid in the development of weapons of mass destruction, support international terrorism, increase the possibility of outbreak or escalation of conflict, or prejudice the development of bilateral or multilateral arms control...". ${ }^{11}$

While US legislation regarding criteria for arms exports is not as clear as the EU Common Position, other legislation (such as the Leahy Law on foreign assistance to human rights abusing forces), have strengthened some of these principles. US presidential administrations also set out 'directives' on US arms export policy, which have previously included regional stability, peaceful conflict resolution, and human rights, alongside the promotion of US security partnerships and support for its defense industry. ${ }^{12}$

\section{Other Major Exporters}

Russia's arms export control system does not have any public 'criteria'-based approach to export licensing..$^{13}$ Nonetheless, Russia is party to Wassenaar and other global arms control agreements, such as the Missile Technology Control Regime. Russia abstained in the UN vote on establishing an ATT, and has not signed it; its diplomacy in relation to the treaty indicated a concern with transfers to non-state actors. ${ }^{14}$ The Federal Service for Technical and Export Control is responsible for ensuring Russian exporters observe national and international law, including
UN Security Council Resolutions and Wassenaar Arrangement control lists. ${ }^{15}$

China's export control regime, which has been strengthened in recent years, likewise appears to be focused primarily on non-proliferation concerns, rather than any related to conflict or humanitarian issues. ${ }^{16}$ However, China did join the ATT in July 2020, despite its past opposition to the treaty. The three principles of Chinese regulations are self defence; peace, security and stability; and non-interference. UN Security Council arms embargoes and China's international commitments are additional factors to be taken into consideration. ${ }^{17}$

Israel's arms export controls are largely focused on preventing transfers to enemy states or to terrorist groups. ${ }^{18}$ Controls related to nonproliferation have been tightened in response to US pressure. Although concerns related to conflict, human rights, and humanitarian concerns do not seem to play a significant role, the Israeli Ministry of Defense website does list human rights as one factor to be considered. ${ }^{19}$ Israel signed the ATT in December 2014, but has not ratified it.

Ukraine is a party to Wassenaar, and has signed, but not yet ratified, the ATT. ${ }^{20}$ Ukrainian export controls were historically rather weak, though as SIPRI documents, they have become significantly stronger since the 1990s. Again, the Ukrainian focus is more on non-proliferation than on criteria related to conflict prevention or civilian protection.

In general, a key difference between EU and non-EU states is the explicit, legal commitment to human rights, IHL and conflict prevention in the former. 


\section{Protecting the Defense Industry}

Alongside these export control laws, policies, and norms, all the major exporters also have policies that emphasize a positive role for arms exports in promoting national and international security, and the domestic defense industry. In the non-EU states, the primacy of national selfinterest is fairly explicit. Indeed, governments frequently invest substantial diplomatic and financial resources in promoting arms exports, often including tolerance of corruption as a means of winning major contracts. ${ }^{21}$

Moreover, previous research has found that there is frequently a gap between many states' willingness to commit to strong arms export controls and their willingness to restrict their arms exports in practice. ${ }^{22}$ When it comes to actual decision-making on exports, states' defense, foreign policy, and military industrial interests, take center stage.

\section{Conflict and Arms Exports in the $21^{\text {st }}$ Century}

What is the record of arms transfers by the leading global arms exporters to participants in the conflicts of the $21^{\text {st }}$ century? For those with a commitment to strong export controls, how does this record match up to such commitments? To answer these questions, we look at each exporter's annual record of weapons supplies to countries engaged in conflict, as well as exporters' own active conflict participation. We also examine the longer-term patterns of arms supply between suppliers and recipients, including in peacetime: can we see, in any cases, a clear increase or decrease in arms supplies with the outbreak or ending of a war?

\section{A. Definitions and Data on Armed Conflict}

We use data on armed conflict from the Uppsala Conflict Data Project (UCDP), ${ }^{23}$ which provides both narrative and quantitative data on (a) statebased conflicts (where at least one conflict party is a state); (b) non-state conflict (between different non-state groups); and (c) one-sided violence against civilians by either state or non-state actors. We investigate two categories of conflict intensity: "War," classified by if a conflict reaches a threshold of 1,000 battle-related deaths (BRD) in a given year, and "Minor Armed Conflict" (MAC) if it reaches a threshold of $25 \mathrm{BRD}$ in a year. ${ }^{24}$

UCDP also lists countries that intervened in support of one side or other in a conflict typically, in internal armed conflicts where there were external participants either on the government or rebel side. In this study, intervening states are treated as being in a state of War or MAC based on the intensity of the conflict in which they intervened in the year in question.

\section{B. Definitions and Data Sources on Arms Transfers}

This report uses two types of data on arms transfers: first, the SIPRI Arms Transfers Database, ${ }^{25}$ which covers all countries, and includes both qualitative and quantitative data on international transfers of major conventional weapons (MCW); and secondly, various national sources of data for those countries where sufficiently detailed data is available. We categorize the level of arms supplied as "substantial" or "minor," based on the level of transfers according to these various data sources. ${ }^{26}$

SIPRI's data covers a wide range of major conventional weapons systems, ${ }^{27}$ but does not include SALW, most components and subsystems, military command, control, and communications 
systems, or military services. Thus, using SIPRI data alone may miss cases where an exporter has maintained a significant supply of such equipment or services to a recipient through a conflict. Even so, SIPRI uses a wide range of sources, official and unofficial, in compiling its data. While it cannot guarantee to capture every MCW transfer within its definition, it is likely that it captures the vast majority.

SIPRI trade registers give detailed qualitative information on both orders and deliveries of MCW for each supplier and recipient. The SIPRI Trend Indicator Value (TIV) converts this information into a numerical measure of the volume of equipment delivered in a given year. (See box).

The SIPRI TIV is not a financial measure. For US weapons systems, the TIV is based on the original unit production cost. For other countries' systems, the TIV is based on SIPRI's assessment of the nearest US equivalent, based on the system's capabilities. ${ }^{28}$ The TIV thus gives a reasonable rough assessment of the extent of arms transfers between a supplier and recipient. It is the only internationally comprehensive, standardized quantitative measure of arms transfers broken down to specific supplier-recipient dyads. Importantly, it is also the only source of detailed information on arms transfers by Russia, China, Israel, and Ukraine.

\section{Additional Arms Trade Data}

The United States publishes detailed data on arms transfers to other states. Much of this data is summarized in the Security Assistance Monitor (SAM) database. ${ }^{29}$ US arms sales go through a number of channels, including government- government Foreign Military Sales, Direct Commercial Sales negotiated by companies and licensed by the Department of State, and some arms sales overseen by the Department of Commerce. In this report, we use the SAM data for arms deliveries, which includes sales through all these channels. The data is currently available up to Fiscal Year 2017. ${ }^{30}$

Under the EU Common Position, EU member states report data on the value of arms export licenses approved, and of actual arms deliveries, broken down by recipient and by military list category. However, the UK and Germany only report license data ${ }^{31}$ For France, Italy, Spain, and the Netherlands, we have therefore used data on deliveries from 2001-2018 for each recipient states, while for the UK and Germany, we have used the value of licenses from 2001-2018. ${ }^{32}$

These additional data sources thus have shorter temporal coverage than the SIPRI data, but for the period for which they are available they allow a fuller picture of the arms transfer practice of the US and EU exporters.

\section{Arms Supplies to Wars since 2000}

Between 2000 and 2018, there were 30 cases of conflict that reached the status of War, or where one-sided violence by a government against civilians on its territory killed at least 1,000 people, in at least one year. These conflicts are geographically, economically, politically diverse, and vary widely in terms of their length, intensity, human consequences, patterns of termination, and technological sophistication. Only the 2003 invasion of Iraq by the US, UK, and Australia, and the 1998-2000 border war between Ethiopia and Eritrea, were clearly definable as inter-state wars. However, a large number of the other, "internal" conflicts, had significant international involvement. ${ }^{33}$

The foreign policy stances adopted by the top 
arms exporters towards conflict actors varied enormously. In some cases, major exporters actively supported one party both diplomatically and with arms sales. For example, a state's war against insurgent groups might be regarded as a legitimate fight against 'terrorists'. In other cases, exporters may have taken a more neutral stance, or regarded the conflict as an internal matter, and not necessarily an obstacle to arms sales. In conflicts like the Ethiopia-Eritrea war, the Democratic Republic of the Congo (DRC) War, and the India-Pakistan conflict, some exporters even armed both sides. ${ }^{34}$

Table 1 shows, for each exporter, how many of the 30 Wars since 2000 they have themselves participated in, how many others where they have transferred substantial quantities of arms to conflict parties during War years, and how many where they have transferred some arms to conflict parties, but not reaching the threshold of "substantial" sales. ${ }^{35}$

It is important to note is that all but one of these eleven exporting countries - China - were themselves participants in at least one War during this period. They were therefore also, a fortiori, suppliers of arms to conflict parties, as they used their own domestically-produced equipment.
In the multi-national coalition conflicts in Afghanistan, Iraq, and Libya, coalition members that were also arms producers, unsurprisingly, continued to trade arms to one another.

Where the exporters were not themselves conflict participants, all of the major arms exporters transferred substantial quantities of arms (in absolute or relative terms) to at least some of the 30 Wars. That is, they transferred or licensed arms to at least one of the active participants in years in which the conflict reached the status of War - and at least minor quantities of arms to several others. ${ }^{36}$ (There were also some cases, not shown in Table 1, where the exporter supplied arms during periods of Minor Armed Conflict, but not in War years). Apart from the Netherlands, all participated in or supplied arms to at least half the Wars.

Figure 1 below presents a summary table of the role of each exporter in each War, showing whether they were participants, major arms suppliers, or minor arms suppliers (that is, to any of the conflict parties while they were involved in the War). It also shows "grey areas" where they exported arms to conflict parties during periods of Minor Armed Conflict, but not War. In a few cases, conflicts have been separated into different periods marked

\section{Table 1: Role of major exporters in arming Wars since 2000}

\begin{tabular}{|c|ccc|}
\hline Country & $\begin{array}{c}\text { Number of Wars } \\
\text { participated in }\end{array}$ & $\begin{array}{c}\text { Substantial arms sales } \\
\text { (number of Wars) }\end{array}$ & $\begin{array}{c}\text { Some arms sales } \\
\text { (number of Wars) }\end{array}$ \\
\hline USA & 4 & 7 & 11 \\
\hline Russia & 3 & 15 & 6 \\
\hline France & 3 & 4 & 12 \\
\hline Germany & 1 & 7 & 7 \\
\hline China & 0 & 7 & 10 \\
\hline UK & 3 & 4 & 11 \\
\hline Spain & 3 & 3 & 9 \\
\hline Israel & 1 & 8 & 8 \\
\hline Italy & 2 & 6 & 8 \\
\hline Netherlands & 3 & 4 & 1 \\
\hline Ukraine & 3 & 7 & 8 \\
\hline
\end{tabular}


by major changes in regime in the country in question, or other significant developments in the conflict (e.g. the role of external parties). Detailed information on the role of different exporters in supplying arms to the various participants to the conflicts will be made available on the project website. This figure provides several insights related to which Wars each exporter has, and has not, supplied.

Figure 1: Top arms exporters' involvement in and arms supplies to Wars
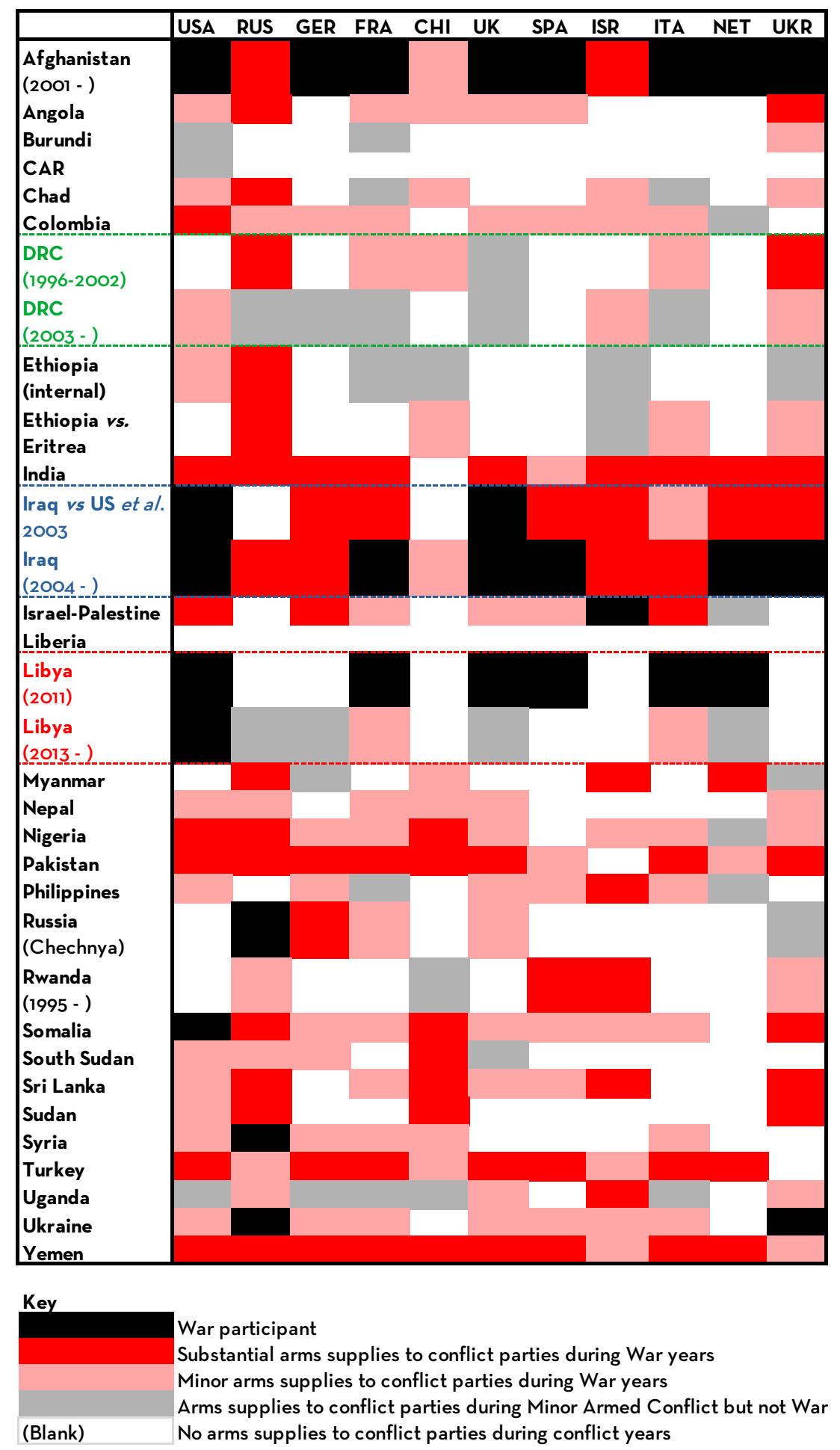

Business as Usual: How major weapons exporters arm the world's conflicts | 14 
First, how exporters treated conflict varied. Some conflicts received arms supplies from almost all of the exporters: India received arms from all major exporters except its military rival, China (although Spain only supplied arms in years of Minor Armed Conflict); Nigeria from all but Spain (although the Netherlands' arms supplies were minor); Pakistan from all but Israel, with whom it does not have formal diplomatic relations; and Turkey from all but Ukraine (although Israel supplied arms only during years of Minor Armed Conflict). All eleven exporters supplied at least one active participant in the Yemen war.

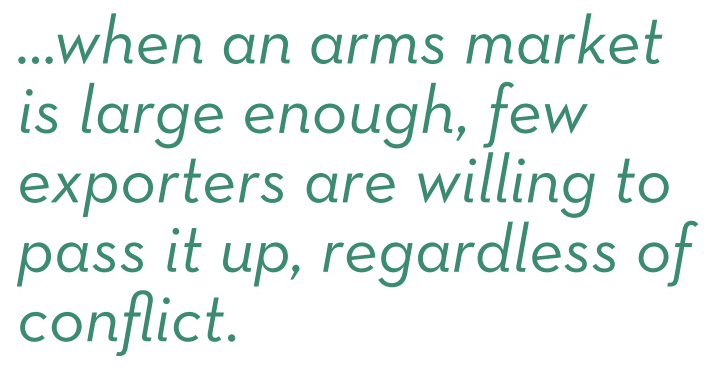

In contrast, many of the African internal conflicts received arms supplies from very few of the exporters. None of the eleven supplied arms (at least through legal channels) to Liberia during the 2011 War, ${ }^{37}$ and few transferred weapons to Burundi and Central African Republic (CAR). Other Wars involving smaller, poorer countries (e.g. Nepal), likewise received arms from few suppliers. This may reflect a policy of selective restraint; or it may reflect the very low level of demand in these countries, especially for hi-tech equipment from the top global producers, independent of any policy choice by the suppliers. African conflicts were also more likely to be the target of arms embargoes, which may also encourage some restraint.

There is a clear tendency for more exporters to supply arms, and in larger quantities, to recipients with more money to spend and where there is generally higher demand for arms. This is almost tautological, but the fact that certain countries like India, Turkey, Saudi Arabia, and Pakistan, have received arms from almost all the exporters suggests that when an arms market is large enough, few exporters are willing to pass it up, regardless of conflict.

Secondly, political factors play a role. Major exporters do not tend to withhold arms from allies and important partners in response to conflict. Different recipients' places in the global system and alliance structures also seem to play a major role in who sells to whom. Western countries are much more willing to exercise restraint - where the recipient is generally seen as being out of line with Western interests, or in the Russian or Chinese geopolitical orbit. Likewise, countries closely allied to the US, such as Colombia, the Philippines, or Israel, may be less likely to buy from Russia or China. Naturally, countries do not tend to sell to their direct rivals. China does not sell to India, and Israel has generally not sold arms to most Arab states. $^{38}$

What is not immediately clear from Figure 1, but can be seen from a closer inspection of the data, is the extent to which the lack of arms sales by an exporter to a country in armed conflict usually reflects absence of arms sales to that country at any time, or at most only occasional, very minor arms transfers. That is, exporters have rarely or never refrained from arming important customers when war has broken out.

Third, we see a pattern of selective, 'low stakes' restraint on the part of the US and European exporters in particular. These exporters sometimes appear willing to stop arms sales in response to conflict or repression, but only where opportunities for sales are in any case limited. In some cases, this has involved the formal imposition of arms embargoes, although armed conflict was not always the direct cause of these. In Myanmar in 1991, for example, the overturning of an election and heavy repression of protests prompted an EU arms embargo. The 1994 EU embargo on Sudan was related partly to the internal conflict and part- 
ly to Sudanese support to terrorist groups.

However, while such embargoes have mostly been observed, in some cases they have not stopped all arms supplies to conflict parties. A UN embargo on DRC during its War in the 1990s-2000s, for example, did not stop arms sales to other war participants in the conflict (i.e. Angola, Chad, Namibia, Rwanda, Uganda, and Zimbabwe), by several exporters. Likewise, an EU embargo on Russia in 2014 in response to its intervention in Ukraine still allowed some existing contracts to be fulfilled.

One interesting case is Libya, where civil war broke out in February 2011. France finished delivering artillery systems to the Libyan government barely weeks before. Once the war began, the UN imposed an arms embargo on the government and soon thereafter many of the major exporters themselves became directly involved in the War against the government. While this case represents a clear abandonment of an arms recipient as a result of the outbreak of conflict, such cases are rare. For the most part states that imposed embargoes did so on countries to whom they were selling little in the first place. ${ }^{39}$

\section{E. Variations on a Theme: Short Profiles of Country Export Patterns}

The United States, the world's largest arms exporter, supplied arms to the great majority of the conflicts considered here, including during War years. Some exceptions suggest a selective policy of restraint: the main DRC war (1996-2002), the Ethiopia-Eritrea war, and Myanmar. In other cases, the US has taken one side of the conflict, for example arming Ukraine against Russia, and Syrian rebels against the government. There were several Wars where it was by far the major supplier to the states involved, including Colombia, Israel, Turkey, and Saudi Arabia and UAE in Yemen.
Russia is the second-largest arms exporter according to SIPRI. In financial terms, it is roughly equal to the UK. It is the most prolific supplier of arms to Wars in the sample, and in the number of Wars to which it supplied substantial arms. The few exceptions are some conflicts involving countries with very low demand (Burundi, CAR, and Liberia), and others where geopolitical factors likely precluded arms sales (Israel, the Philippines, and the US and UK during the Iraq invasion).

Germany sold most arms to the countries that were generally the biggest arms buyers, such as Egypt, India, Pakistan, and Turkey, as well as to its NATO allies, the UK and US, during the Iraq invasion, which it otherwise opposed. Germany was also the largest European supplier to Israel and Russia. It generally avoided arms sales to most of the African conflicts, with some exceptions, in particular Nigeria and countries involved in the AMISOM mission in Somalia.

France armed most conflicts, though there were a number of cases where this only occurred during years of Minor Armed Conflict. Its selective restraint, sometimes partly related to geopolitical factors, include the Ethiopia-Eritrea war, Myanmar, and Sudan. Others are cases of low-demand, or in the case of Rwanda, poor relations with the buyer. Like Germany, its largest arms sales were to the "high-demand" countries. Egypt has become a particularly major customer in recent years, coinciding with its involvement in the Yemen war.

China supplied more African conflicts than other similar-sized exporters, was the major supplier to Pakistan, and was a substantial supplier to some of the generally lower-demand countries such as Nigeria, Ethiopia (in Somalia), Myanmar (though in this case less in 2017, the year of most intense violence) South Sudan, Sri Lanka, and Sudan.

The warring states China did not sell arms to were probably due to geopolitical reasons (either on the buyer or seller's part or both), such as Colombia, 
India, Israel, the Philippines, the UK and the US. It has maintained the arms embargo against Libya.

The UK, after the USA, was the major exporter itself most involved in overseas wars. Otherwise, the Wars it armed most were those involving the high-demand countries, but it supplied at least minor quantities of arms in a clear majority of all Wars. The conflicts the UK didn't arm mostly involved low demand countries, though there are some examples of possible selective restraint: Ethiopia-Eritrea, Myanmar, Sudan, and Syria.

Spain is generally a lower-level arms exporter, but its pattern of sales and lack of sales, aside from scale, are not greatly different from other European exporters.

Israel behaved somewhat differently than other suppliers, in that it was precluded from the arms markets of most Arab and other Muslim states. It was therefore the only country not to sell to Pakistan, and one of the few not to sell to Saudi Arabia or UAE. It was a substantial supplier to a number of lower-demand states, such as Myanmar, Philippines, Rwanda, Sri Lanka, and Uganda, although its major arms customer in recent years has been India.

Italy was the only European supplier to transfer arms to either Ethiopia or Eritrea (namely the latter) during their war. Otherwise, its pattern was similar to other European suppliers, with substantial supplies to major buyers (including substantial arms to Israel in 2014), a few cases of selective restraint in line with embargoes, and a lower likelihood of selling arms to the smaller buyers.

The Netherlands supplied far fewer conflicts than any other of the major exporters, which may be partly due to being a much smaller exporter but may also reflect policy choice. In particular, it did not supply arms to any African conflict, except for the one it directly participated in, namely Libya (i.e., arming itself and its allies), and minor arms supplies to Nigeria during years of Minor Armed Conflict. However, like most other exporters, it supplied substantial arms to the generally high-demand countries, namely India, Turkey, and the UAE. Interestingly, it appeared to break the EU arms embargo against Myanmar in 2017 by supplying a VIP transport aircraft.

Ukraine supplied more wars than other lower-tier exporters (18, including the ones to which it was party). It was a relatively major supplier to a number of smaller buyers, such as Angola, DRC, Sri Lanka, Sudan, and Uganda, as well as lesser quantities to Burundi, Eritrea, and Rwanda. Like almost everyone else, it sold substantial arms also to India and Pakistan. However, it was the only major exporter that did not supply arms to either Turkey or most of the participants in the Yemen war. This may be a matter of Ukraine's cheaper, lower-tech arms being more attractive to poorer buyers, but not those able and willing to spend more.

Overall, looking across all eleven major exporters, there is little evidence that conflict acts as a restraining factor on arms transfers. Indeed, there is not a single clear case where a major arms market was abandoned clearly in response to the outbreak of conflict. There are some examples (e.g. Libya) where smaller export customers were forsaken, or of arms transfers only starting after a conflict is over. However, even in some of these instances, there is simply insufficient clear data for this analysis to come to a firm conclusion that conflict was the reason for the lack of arms sales.

\section{Statistical Analysis of Conflict and Arms Sales Data}

For each of the eleven exporters, we conducted a large-scale statistical analysis (See Box for de- 
The study used several different regression models, treating each exporter separately. The results reported here are for random effects panel logistic regressions, using the SIPRI TIV data, where the dependent variable was a binary variable taking the value 1 for a recipient-year pair if the exporter delivered some MCW to the recipient that year, and o otherwise. The 162 recipient states in the sample included all countries with sufficient data for all the variables. ${ }^{40}$

The key independent variables of interest are variables for War and Minor Armed Conflict, using binary variables taking the value 1 or 0 depending on whether the recipient in question was involved in a War, respectively MAC, in a given year or not. Both the current and previous-year values of these variables were used, to allow for possible delayed responses by exporters.

In addition, we controlled for the effect of a number of other key variables:

1. A binary variable measuring whether or not the recipient was a recent customer of the exporter in question (specifically, whether they had received a certain minimum TIV level over the previous 5 years). The logic of this is that arms transfer relationships in many cases appear to be long-term, ongoing affairs, rather than simply one-off transactions.

2. A number of variables relating to the recipient's capacity to buy arms. These were levels of military expenditure; GDP or GDP per capita (only one of these was used in each case); and the level of arms imports from all other suppliers. (Thus, the regression for France used a variable measuring each recipient's total arms imports, minus their imports from France).

3. A number of other potentially relevant variables, including NATO membership, level of democracy (measured by the Polity 5 dataset), and whether the recipient is in Africa.

4. The Afghanistan, Iraq, and Somalia conflicts were treated distinctly from the main War and Minor Armed Conflict variables. We would not expect the US and UK, for example, to withhold arms from their coalition allies in Afghanistan and Iraq; thus, treating involvement in these conflicts the same as other wars might mask any tendency for restraint in other conflicts. Likewise, the UN-approved African Union AMISOM mission in Somalia might be viewed more favorably by some exporters than other conflicts. We also observed some increase in MCW imports by several AMISOM members, who were hitherto very minor importers. Binary $1 / 0$ variables were used for participation in each of these conflicts as part of multinational forces with UN mandates.

5. "Interaction" variables measuring whether the recipient was at War/MAC and was a "recent customer". The intuition here was that an exporter might be reluctant to abandon an existing customer when conflict breaks out, but might be willing to refrain from initiating arms sales to a new country that is at war.

A full description of the methodology and results will be made available on the project website. 
tails), with the goal of exploring the relationship, if any, between their arms exports to different countries, and the recipients' involvement in armed conflict. The analysis used the SIPRI TIV data, measuring exports to 162 potential recipient states between 1990 and 2018. Each exporter was analyzed separately, to allow us to explore different patterns of behavior by each. The model used seeks to identify the factors that significantly affect the probability of at least some MCW transfers taking place between the supplier and the recipient in any given year - regardless of the quantity of such transfers. By combining this evidence with that from the previous section, we hope to gain a clearer overall picture.

Two variables had a highly or very highly significant effect on the probability of MCW transfers for each of the 11 exporters: 1) whether the recipient was a recent customer, and 2) the level of arms imports from all other suppliers. In all cases, there was a less than $1 \%$ chance, and in most a less than $0.1 \%$ chance, that these results could have occurred randomly. This confirms that arms sales relationships tend to be ongoing, and that recipients' overall demand for arms is a key factor in whether they will receive arms from any individual supplier.

For the great majority of exporters, variables measuring the recipients' capacity to buy arms were highly significant. In particular, the recipient's level of military spending was a significant, positive factor for all of the top six exporters, and for Ukraine. For three countries, the level of GDP or GDP per capita has a positive and significant effect; in all cases except Spain and the Netherlands, at least one of these "capacity" variables was relevant.

However, for Russia, China, and Ukraine, higher GDP per capita significantly reduces the probability of arms transfers to a recipient. This suggests that the cheaper, often lower-tech weapons systems offered by these countries, compared to the western suppliers, are more likely to be of interest to poorer countries. For all three, military expenditure is significant and positive, so financial capacity is still relevant. The question is more how buyers spend their limited resources.

The most striking result was that for none of the exporters does conflict - either War or Minor Armed Conflict - reduce the probability of arms sales. Indeed, Russia appeared to be very significantly more likely to export arms to countries at War. ${ }^{41}$ In the case of Israel, Minor Armed Conflict made a country very significantly more likely to receive arms (although all-out War did not have a significant effect). The same result applied for France, although the result was only weakly significant. ${ }^{42}$ Somewhat surprisingly, the Netherlands was significantly more likely to sell arms to countries at War, ${ }^{43}$ if they were also recent arms customers. For all of the other exporters, neither War nor Minor Armed Conflict had a significant effect either way. ${ }^{44}$

\section{Overall Demand for Arms Imports}

The analysis so far has focused on individual exporters' arms sales. We also examined the factors affecting the total level of MCW imports by each country, and the probability that a country would receive at least some transfers (from any supplier) in a given year. The purpose of this is to understand the factors driving overall demand for arms by each recipient. In contrast, the results discussed above for each individual exporter may reflect a combination of supply and demand factors - the exporter's willingness to sell, and the recipient's willingness (and ability) to buy.

Similar to the results for many individual exporters, we found that a country's level of military expenditure and GDP - especially the former - were both highly significant in determining the probability of receiving some MCW transfers (from any supplier). Military expenditure also very significantly affected the level of such imports. War, and to a lesser extent, Minor Armed Conflict, 
also had a very significant positive effect on both the likelihood and level of imports. Involvement in Afghanistan and Somalia tended to increase demand for arms imports, but the result was only weakly significant. ${ }^{45}$

\section{The implication of this is that countries in-} volved in conflict were more likely to buy arms - just not from most of the top eleven exporters. This suggests that the increased arms supplies came either from those of the major exporters where a positive impact of conflict was observed (chiefly Russia in the case of all-out War), or from other, smaller exporters.

\section{Conclusions}

This report has explored the relationship between armed conflict and the supply of arms by eleven major arms exporters, with the aim of assessing to what extent - if any - a potential recipient's involvement in armed conflict may act as a restraint on arms transfers. We approached this both through a descriptive analysis on arms supplies to conflict countries, and by large-sample statistical analysis of exports to 162 potential recipient countries from 1990.

The descriptive analysis found that all eleven exporters supplied arms, sometimes in substantial quantities, to numerous countries engaged in war. Indeed, all but the Netherlands either participated themselves and/or armed participants in at least half of the 30 conflicts considered. Of course, there were also wars, or sides in wars, that different exporters did not arm. This appeared mostly to be related either to global political and diplomatic factors, like hostile relationships with the countries in question, or to the countries' limited demand for arms imports in the first place. What appears as restraint may therefore represent lack of opportunity for sales, or where it is restraint, it is at low cost for the exporter and its arms indus- try. In general, the countries offering the largest potential arms sales opportunities, like India, Pakistan, Turkey, Egypt, and the Gulf states, proved irresistible markets for almost all the exporters, except where precluded by political factors.

Nonetheless some variation could be observed between the exporters, with Russia being clearly the most prolific arms supplier to wars, and the Netherlands the least.

Complementing this, the regression analysis failed to find any robust evidence that potential recipients' involvement in armed conflict acted as a restraint on arms sales for any of the exporters, once we controlled for other factors. Indeed, in some cases the reverse was true. Arms sales largely follow the demand and are often dependent on established relationships between buyer and seller which sellers are typically reluctant to abandon, regardless of concerns over the potential impact on conflict.

While this may appear at odds with the arms export policies and agreements of the European producers and to some extent the United States, this conclusion is likely to be greeted with weary nods of recognition by campaigners on the issue. On numerous occasions, politicians have assured campaigners of the "rigorous and robust" nature of export controls (UK government, passim), justifications for the wars being fought, or explanations as to the vital nature of relations with the recipient state. Of course, Russia, China, Israel, and Ukraine - in contrast to the Western exporters - have never made human rights, humanitarian issues, or conflict in general a specific criterion in their export control policies. And while the US does give some role to these, it has also always clearly emphasized the role of national security and foreign policy interests as a key consideration.

This is not an argument for abandoning efforts to control arms sales. Rather, it points to the fact that, as was pointed out in section $2,{ }^{46}$ getting 
states to sign up to stronger export controls is one thing, but getting them to implement them in practice, especially when it comes to important customers, requires a lot more work. Current moves to restrict arms sales to Saudi Arabia over the war in Yemen by several states may be an indication that this second, harder task is beginning to make tentative progress.

While this data-centered analysis cannot tell us much about the 'why' of arms sales policies - that will be addressed in the case studies that will constitute the next stage of this project - a few thoughts are offered here.

\section{A recent history of arms sales is one of the strongest predictors of arms sales in the present.}

Generally, the drive to export seems to be stronger than humanitarian or conflict concerns in most circumstances. But an important factor in how exporters respond to conflict may be the framing of the conflict adopted by the government, which may in turn be influenced by the media, international allies, the foreign policy and security community, and perhaps public opinion. This framing is itself not likely to be independent of the exporter's prior relationship with the country in question, including its arms trade relationship. Thus, a conflict that is framed as part of the "war on terror", or as a legitimate defense of national sovereignty in the face of insurgency, is much less likely to be seen as an obstacle to arms sales. Non-western exporters like Israel and Russia have also adopted the "war on terror" framing on occasion (for example Russia argues that the Assad regime in Syria is fighting terrorism). And countries that are already allies or important partners, and/ or previously established arms customers, such legitimizing may well be more likely. In contrast, where conflicts are framed as state repression of its people, as tragic or incomprehensible ethnic conflicts, or as the result of corruption and state fragility, exporters are more likely to halt to arms sales (which were usually already at low levels in any case).

A recent history of arms sales is one of the strongest predictors of arms sales in the present. This might suggest that exporters will frame their narrative of a conflict around their existing relationship with the country involved, including around their importance as a customer for arms sales. Occasionally, as for example in the case of Russia in relation to the Ethiopia-Eritrea war, exporters may simply see the outbreak of conflict as an arms sales opportunity. The regression results suggest this may be true of France and Israel as well. But this appears to be less common for many of the major exporters. It is not, usually, that the conflict acts as a particular restraining factor; rather, in the absence of a substantial pre-existing arms sales relationship, most exporters will not take advantage of the potentially increased demand for arms the conflict affords. Here at least we perhaps see some partial, tenuous indication of restraint on the part of many of the exporters, although at a fairly minimal moral bar, like a habitual thief who refrains from robbing an injured person lying in the street. 


\section{ENDNOTES}

1 See for example Cato Institute, Risky Business: The Role of Arms Sales in U.S. Foreign Policy (March 2018), https://www.cato.org/policy-analysis/riskybusiness-role-arms-sales-us-foreign-policy; Amnesty International, Blood at the Crossroads: Making the Case for a Global Arms Trade Treaty (2008), https://controlarms.org/wp-content/uploads/2018/03/ act300112008en.pdf; Oxfam Policy \& Practice, Africa's Missing Billions: International Arms Flows and the Cost of Conflict (October 2007), https:// policy-practice.oxfam.org/resources/africas-missing-billions-international-arms-flows-and-the-costof-conflict-123908/; David Southall, and Bernadette O'Hare. 'Empty Arms: The Effect of the Arms Trade on Mothers and Children.' British Medical Journal Vol. 325 No. 7378 (December 2002), pp. 14571461, https://www.ncbi.nlm.nih.gov/pmc/articles/ PMC139041/; Small arms and light weapons: Report of the Secretary-General, UN SC Report S/2019/1011 (December 2019), https://www.securitycouncilreport.org/atf/cf/\%7B65BFCF9B-6D27-4E9C-8CD3CF6E4FF96FF9\%7D/s_2019_1011.pdf.

2 The methodologies are: First, a direct juxtaposition of arms sales and conflict data (from the SIPRI), that revealed numerous examples of major arms producers continuing to provide arms supplies to recipients engaged in major armed conflicts. Second, statistical regression analysis for each exporter between 19902018, controlled for a range of relevant demand and supply factors.

3 See note 1 supra.

4 Data on suppliers of conventional weapons is drawn from the Stockholm International Peace Research Institute (SIPRI) and national sources, while for conflict, we use the Uppsala Conflict Data Project (UCDP). The top 11 are selected based on SIPRI data for arms exports for the period 2009-2018.

5 E.g. Keith Krause, Arms and the State: Patterns of Military Production and Trade (Cambridge: Cambridge University Press, 1992); C. Sharkey, "The International Arms Trade - By Rachel Stohl and Suzette Grillot," Political Studies Review Vol. 10 no. 2 (2012), pp. 265-266
6 "ROCA (United Nations Register of Conventional Arms)", https://www.unroca.org/.

7 The Wassenaar Arrangement, https://www.wassenaar.org/.

8 See "UN Programme of Action on Small Arms and Light Weapons.", https://www.reachingcriticalwill.org/ disarmament-fora/salw.

9 The United Kingdom left the European Union in January 2020. Since it was a member throughout the period covered by this study, references to EU member states in this report include the UK.

10 Former President Trump announced a decision for the US to "withdraw" its signature in 2019. The new Biden Administration's plans on this are not yet clear.

11 "22 U.S. Code $\S 2778$ - Control of Arms Exports and Imports." LII / Legal Information Institute, https:// www.law.cornell.edu/uscode/text/22/2778.

12 E.g. the Obama Administration's Conventional Arms Transfer Policy of January 2014, https:// obamawhitehouse.archives.gov/the-press-office/2014/01/15/presidential-policy-directive-united-states-conventional-arms-transfer-p.

13 Saferworld, Russia's Impact on Global Security: Russia's Arms Trade (2007), https://www.saferworld.org.uk/downloads/pubdocs/070424\%20-\%20 FASC $\% 20$ Russia $\% 20$ Global $\% 20$ Security $\% 20$ Submission.pdf

14 Julian Cooper, "Russian Arms Export", in L. Lustgarten, Law and the Arms Trade: Weapons, Blood and Rules (Oxford: Hart, 2020) p. 313.

15 Cooper "Russian Arms Export", note 15 supra, p. 299.

16 For an English-language discussion of recent developments in China's export control system, see Royal United Services Institute, Upgrading to a New, Rigorous System (March 2016), https://rusi.org/sites/ default/files/201603_op_upgrading_to_a_new_rigorous_system_en.pdf

17 Anna Stavrianakis and He Yun, "China and the Arms Trade Treaty. Prospects and Challenges" Safer World (London, 2014) p. 9

18 SIPRI, "Israeli Arms Transfers to Sub-Saharan Africa", https://www.sipri.org/publications/2011/ 
sipri-background-papers/israeli-arms-transfers-sub-saharan-africa.

19 Israeli Ministry of Defense, Defense Export Control Policy, http://www.exportctrl.mod.gov.il/English/ Pages/Defense-Export-Control-Policy-.aspx

20 Arms Trade Treaty, ATT Signatories that have not yet ratified, accepted or approved the Treaty, https:// thearmstradetreaty.org/hyper-images/file/List $\% 20$ of $\% 20$ ATT $\% 20$ Signatory $\% 20$ States $\% 20(07 \% 20 \mathrm{Au}-$ gust $\% 202020) /$ List $\% 20$ of $\% 20$ ATT $\% 20$ Signatory $\% 20$ States\%20(07\%20August\%202020).pdf

21 Sam Perlo-Freeman, "Red Flags \& Red Diamonds", World Peace Foundation Occasional Paper No. 21 (September 2019), https://sites.tufts.edu/wpf/ red-flags-and-red-diamonds/

22 Jennifer Erickson, Dangerous Trade: Arms Exports, Human Rights and International Reputation (New York: Columbia University Press, 2018), http://cup.columbia.edu/book/dangerous-trade/9780231170963

23 Uppsala Conflict Data Program, Recorded Fatalities in UCDP Organized Violence 1989-2019, https:// ucdp.uu.se

24 For the purpose of this analysis, in cases where a state was engaged in multiple internal conflicts, it was treated as being in a War state if these conflicts totaled at least 1,000 BRD. A country was also treated as being in a state of War if deaths from one-sided violence at the hands of state forces reached at least 1,000 in a given year, or at least MAC if there were 25 deaths.

25 SIPRI Arms Transfers Databese, https://www. sipri.org/databases/armstransfers

26 "Substantial" arms supplies is defined as either: 1) A TIV value of deliveries of MCW of at least 50 to conflict participants during years of War between 2000-2018; 2) A TIV value of at least 100 including also years of War from 1990 onwards, providing the War years before 2000 are assessed to form part of a continuous conflict that also includes that which occurred since $2000 ; 3$ ) At least $10 \%$ of the total TIV value transferred to conflict parties during War years from 2000-2018, provided this TIV value is at least 10; or 4) Arms transfers to conflict parties worth a financial value of at least $€ 100$ million (based on national data) during War years for which data is available.
27 For details see SIPRI Arms Transfers Database, Sources and Methods, https://www.sipri.org/databases/armstransfers/sources-and-methods

28 See note 28 supra. $s$

29 Security Assistance Monitor, Arm Sales, http:// www.securityassistance.org/content/arms-salesdashboard

30 i.e. October 2016 - September 2017.

31 A large proportion of UK arms exports are conducted using "open licenses", which allow unlimited transfers during their period of validity, and for which no financial value is given. Figures for UK license values are therefore severely understated.

32 Delivery figures for France are missing for 20022003, and for the Netherlands for 2001, 2003, and 2004. We use in their place the value of licenses issued, divided by 2.87 for France for 2002-2003, and by 1.67 for the Netherlands for 2001, 2003, and 2004, being the average ratio of licenses to deliveries for these countries over the years for which both sets of data are available.

33 Two important ongoing interstate armed conflicts, between India and Pakistan, and between Armenia and Azerbaijan, never reached the status of War between 2000 and 2018 and thus are not included in the dataset, although the latter may well have done so in 2020 .

34 The India-Pakistan conflict never reached the status of War since 2000, although India's Kashmir conflict, in which Pakistan is significantly involved, did.

35 "Substantial" arms supplies is defined as either: 1) A TIV value of deliveries of MCW of at least 50 to conflict participants during years of War between 2000-2018; 2) A TIV value of at least 100 including also years of War from 1990 onwards, providing the War years before 2000 are assessed to form part of a continuous conflict that also includes that which occurred since 2000 ; 3) At least $10 \%$ of the total TIV value transferred to conflict parties during War years from 2000-2018, provided this TIV value is at least 10; or 4) Arms transfers to conflict parties worth a financial value of at least $€ 100$ million (based on national data) during War years for which data is available.

36 The minimum threshold for counting an exporter 
as supplying "minor" quantities of arms were either a TIV value greater than 0 during a War year, orders agreed for MCW during a War year, recorded in the SIPRI database (but not necessarily delivered), and/or at least $€ 1$ million of licenses/deliveries according to national data during a War year.

37 Many African countries were transit points for SALW, either smuggled or covertly authorized by governments, and some (e.g. Ethiopia) manufactured ammunition that was sold to belligerents, but no major exporter was significantly involved in supplying arms to these 'low stakes' conflicts.

38 It is possible that recent "normalization" deals will change this, although Israel has never transferred arms to Egypt, despite having diplomatic relations with them since 1979.

39 Many countries have however continued to sell arms to Egypt, Turkey, and UAE, although these countries have actively supported various armed factions in Libya, often in violation of the UN arms embargo.

40 Other regressions were carried out using the level of the TIV value, whose results will be reported in a subsequent publication. For the US and EU exporters, additional fixed effects panel data models were carried out using the national data on licenses or deliveries. The results of the latter will be reported on the project website. None of these gave a fundamentally different picture.

41 At the $0.1 \%$ level of significance, that is a less than $0.1 \%$ probability of the result occurring randomly. Somewhat paradoxically, this effect seemed to be partially offset if the country in question was a recent Russian arms customer, although this was only significant at the $10 \%$ level (betweeen a $5 \%$ and $10 \%$ probability of occurring randomly).

42 At the $10 \%$ level of significance.

43 At the 5\% level of significance.

44 Some other variables had a significant effect for some exporters. The US, Germany, France, and Ukraine were significantly more likely to sell arms to countries that were involved in the AMISOM mission in Somalia at the time, while Italy was significantly less likely to do so. For Spain, the Netherlands and Ukraine, involvement in Afghanistan increased the odds, while for the UK it reduced them. The US,
Italy, and the Netherlands were significantly more likely to sell to NATO members, while Russia, China, and Ukraine were less likely to. Democracy had no significant effect for any exporter except France, where an increase in the level of democracy had a significant negative effect on arms sales. Germany and the Netherlands were significantly less likely to sell arms to countries in Africa, other factors being equal.

45 At the $10 \%$ level

46 Erickson "Dangerous Trade", see note 23 supra. 
